\title{
Coping strategies of nurses in the care of patients with head and neck neoplasms*
}

\author{
Estratégias de enfrentamento de enfermeiros no cuidado aos \\ pacientes com neoplasias de cabeça e pescoço \\ Estrategias de enfrentamiento de enfermeros en el cuidado a \\ los pacientes con neoplasias de cabeza y cuello
}

Naira Agostini Rodrigues dos Santos ${ }^{1}$, Antonio Tadeu Cheriff dos Santos ${ }^{1}$, Rildo Pereira da Silva ${ }^{1}$

How to cite this article:

Santos NAR, Santos ATC, Silva RP. Coping strategies of nurses in the care of patients with head and neck neoplasms. Rev Esc Enferm USP. 2016 ;50(4):569-577. DOI: http://dx.doi.org/10.1590/S0080-623420160000500005

* Extracted from the end-of-course dissertation "Enfrentamento de enfermeiros no cuidado a pacientes com neoplasias de cabeça e pescoço”, Residência Multiprofissional, Instituto Nacional de Câncer José Alencar Gomes da Silva, 2014.

${ }^{1}$ Instituto Nacional de Câncer José Alencar Gomes da Silva, Núcleo de Pesquisa e Estudos Qualitativos, Rio de Janeiro, RJ, Brazil.

\begin{abstract}
Objective: To understand and describe the experience of the development of coping strategies during the professional life of nurses providing care to patients with facial image alteration. Method: Descriptive qualitative study with a hermeneutic-dialectic framework conducted in the head and neck ward of a reference hospital in Rio de Janeiro, with the participation of eight nurses and data produced through semistructured interviews conducted between June and August 2013. Results: Three major impressions were found: initial estrangement and complexity, consisting in the care given to patients with facial image alteration; a threshold between estrangement and coping, corresponding to the emergence of coping strategies during care; and image-likeness as a (re)cognition of the individual with facial image alteration in the development and consolidation of coping strategies during care. Conclusion: Among other contributions, the identification and understanding of coping strategies may contribute to better qualify nursing education and care.
\end{abstract}

\section{DESCRIPTORS}

Head and Neck Neoplasms; Adaptation, Psychological; Oncology Nursing; Qualitative Research.
Corresponding author:

Antonio Tadeu Cheriff dos Santos Instituto Nacional de Câncer José Alencar Gomes da Silva

Núcleo de Pesquisa e Estudos Qualitativos Rua Marques de Pombal, $125-7^{\circ}$ andar CEP 20230-240 - Rio de Janeiro, RJ, Brazil cheriff@inca.gov.br
Received: $10 / 22 / 2015$

Approved: 06/28/2016 


\section{INTRODUCTION}

A total of 15,290 new cases of head and neck cancer (oral cavity only) was estimated in Brazil for 2014(1). This type of cancer requires adaptation and control strategies by health professionals, generating challenges for nurses as they constantly experience the suffering of patients ${ }^{(2-7)}$.

In the education of nurses, the care to patients with facial image alteration is conceived as a complex and impressive experience that may affect the care and interaction between nurse and patient. The care to head and neck cancer surgical patients is a potential threat to the physical and emotional balance of nurses ${ }^{(3-5,8)}$. The occupational reality requires the ability to adapt to stressing situations that require the development of a coping process ${ }^{(3-6,8)}$. These coping strategies are either learned and maintained or not throughout the life of an individual, depending on reinforcement schemes experienced during the professional history of the individual ${ }^{(2,8)}$, and they may be seen as a health protection factor for nurses inserted in the work context ${ }^{(9)}$. However, in addition to the coping strategies and their implementation, the research sought to interpret the several speeches, evidencing the particularities, confluences, and distinctions of the coping processes evoked through the life experience, the field of work, the complexity of the social relations of these professionals, and the meanings and senses attributed by them to their experiences ${ }^{(10)}$.

Thus, the aim of this study was to understand and describe the professional experience of coping developed by nurses providing care to patients with facial image alteration.

\section{METHOD}

This was a qualitative, descriptive study guided by the hermeneutic-dialectic, method adopted as a dual function reference: as a configurator of the categories and questions related to the object and as an analysis procedure of the empirical material. The union of hermeneutics with dialectics is productive in conducting a process that is both understanding and critical of the social reality ${ }^{(11)}$. It is noteworthy that, within the specificities of this job, the core and predominant theoretical-methodological guidance presents an interpretative-comprehensive nature, considering as relevant not the supposed truth of the phenomena themselves, but the symbolic truth translated by meanings and senses attributed to the phenomena by the participants in the research. Thus, the symbolic attributions to the experience of developing coping strategies were found to be more relevant than the coping strategies themselves, which are pointed out only as elements that converse with the empirical categories found in the speeches ${ }^{(10-11)}$.

The data production technique was the biographical interview, characterized by a respect for the individuality and specificity of the interviewee, seeking a dialogue through which "the individual talks about the representation they have of the facts in their life according to categories of values and their time codes"(12). In this sense, prior to stimulating the professional life narrative, personal and professional data related to gender, age, religion, time, and type of education were collected through a script. Then, the participants were requested to provide a report on the beginning, development, and consolidation of their experiences regarding coping strategies during the care to patients with facial image alteration. The audio recordings were transcribed to enable a comprehensive approach by researchers. The analysis was conducted under the "comprehension/interpretation" scheme, which presupposes both exercises, hermeneutic (i.e., extraction of empirical categories and attributed meanings) and dialectic (i.e., correspondence between empirical and theoretical categories). The organization and analysis of data involved: (a) comprehensive reading; (b) identification of underlying meanings; (c) problematization of ideas and senses and articulation with socio-cultural meanings; (d) elaboration of a synthesis of senses from the dialogue between empirical data and theoretical contributions; (e) elaboration of schemes of interpretative analysis processes containing the categorization, empirical-theoretical correspondences, and synthesis of senses. Eight nurses participated in the study according to the following criteria of inclusion: five years or more of experience in head and neck oncologic nursing; and agreement to participate in the study. The study was conducted between May and December 2013 in an oncologic reference hospital in Rio de Janeiro with the approval of the research project by a research ethics committee, under protocol 272.883 .

\section{RESULTS}

The age of the participants ranged between 32 and 56 years. In relation to religious orientation, four were Catholic, three were Spiritualist, and one was agnostic. Professional experience ranged from eight to 30 years. Only one of the interviewees had no specialization in oncologic nursing. All of them reported a lack of specific training to deal with the complexity inherent to patients with facial image alteration.

With the objectives of the research as a reference, 46 reports of speeches distributed into three empirical categories were selected. Initial estrangement of coping contained 16 reports; Emergence of coping strategies contained 14 reports; and Development and consolidation of coping strategies contained 16 reports. Within each empirical category, the reports were regrouped into empirical subcategories.

The category Initial estrangement of coping covers the meanings of the first reactions to the initial impact of the experience in patient care.

The category Emergence of coping strategies covers the meanings of the processes of cognitive changes and behavioral efforts in order to manage the specific demands of patient care.

The category Development and consolidation of coping strategies covers the meanings of the cognitive and behavioral development applied to manage to specific demands related to patient care. 
Chart 1 - Relation between empirical categories and subcategories.

\begin{tabular}{|c|c|}
\hline EMPIRICAL CATEGORIES & EMPIRICAL SUBCATEGORIES \\
\hline Initial estrangement of coping & $\begin{array}{l}\text { Reactions to mutilation; Reactions to the social context of the } \\
\text { patient; Empathy and feminine identity; Reactions to the unknown; } \\
\text { and Mutilation as a cure. }\end{array}$ \\
\hline Emergence of coping strategies & $\begin{array}{l}\text { Coping through imagination; Coping through affection; Coping } \\
\text { through altruism; Coping through the professional duty; Coping } \\
\text { through the separation of professional and personal lives; Coping } \\
\text { through study; Coping through teamwork; Coping through self- } \\
\text { esteem; and Coping through religiosity. }\end{array}$ \\
\hline $\begin{array}{l}\text { Development and consolidation } \\
\text { of coping strategies }\end{array}$ & $\begin{array}{l}\text { Consolidation of a strategy through humanism; Consolidation of } \\
\text { a strategy through belief in cure by mutilation; Consolidation of } \\
\text { a strategy through study; Consolidation of a strategy through the } \\
\text { professional duty; Consolidation of a strategy through the model of } \\
\text { struggle for life; Consolidation of a strategy through affection and } \\
\text { effectiveness in care; Consolidation of a strategy through teamwork; } \\
\text { and Consolidation of a strategy through belonging to social groups. }\end{array}$ \\
\hline
\end{tabular}

Source: Interviews of the research.
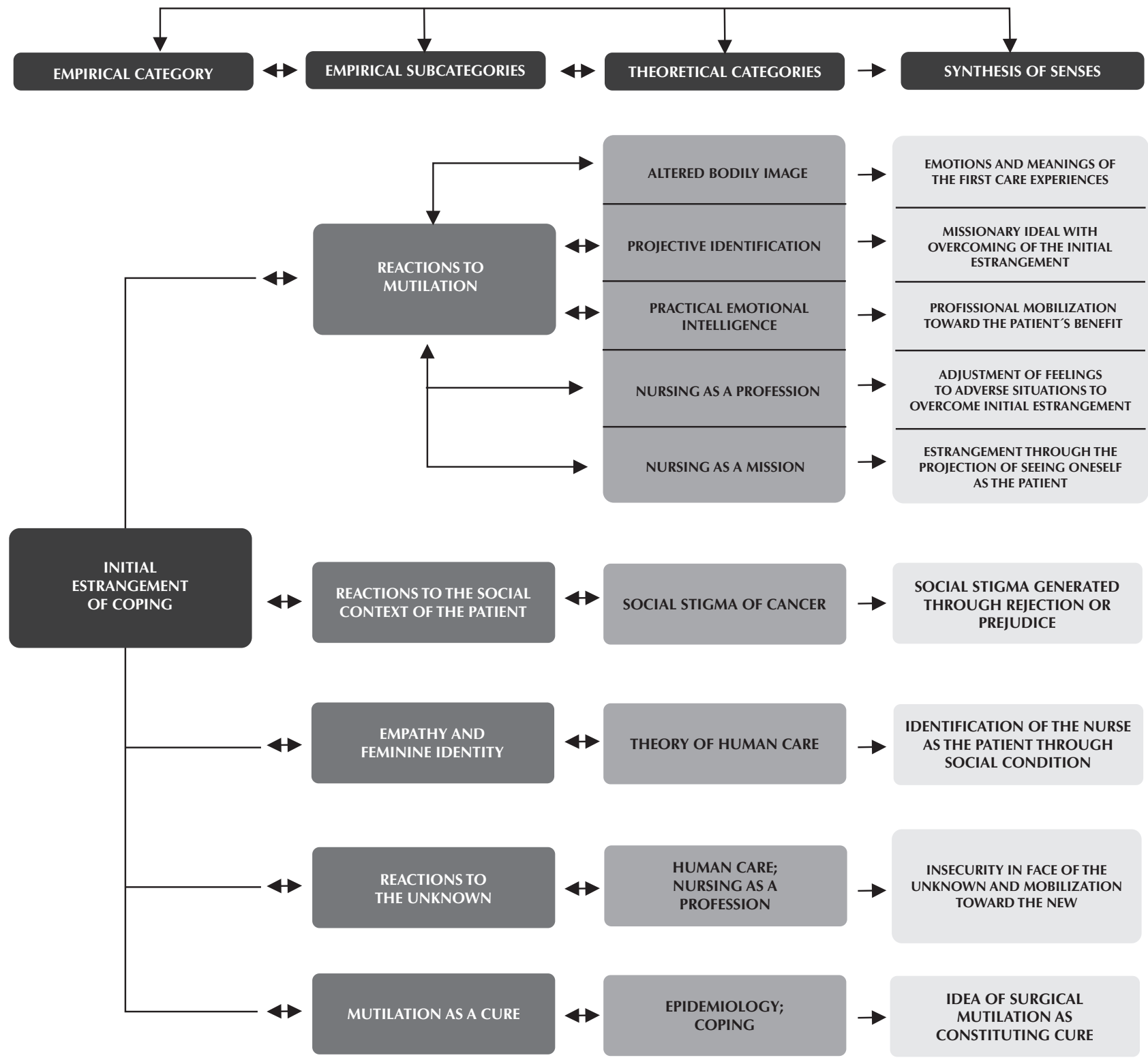

Figure 1 - Scheme of the interpretative analysis process related to the empirical category Initial estrangement of coping. 


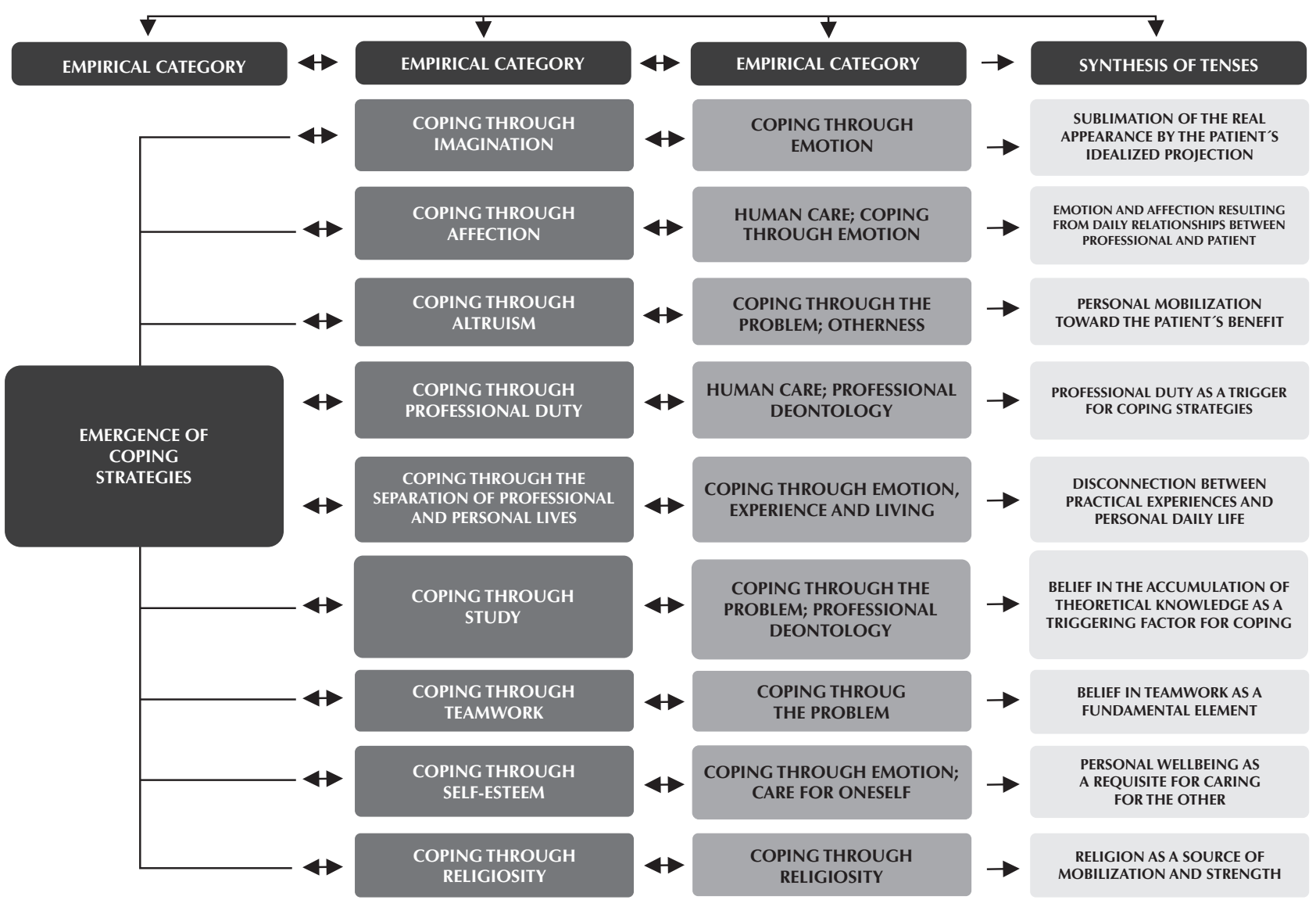

Figure 2 - Scheme of the interpretative analysis process related to the empirical category Emergence of coping strategies.

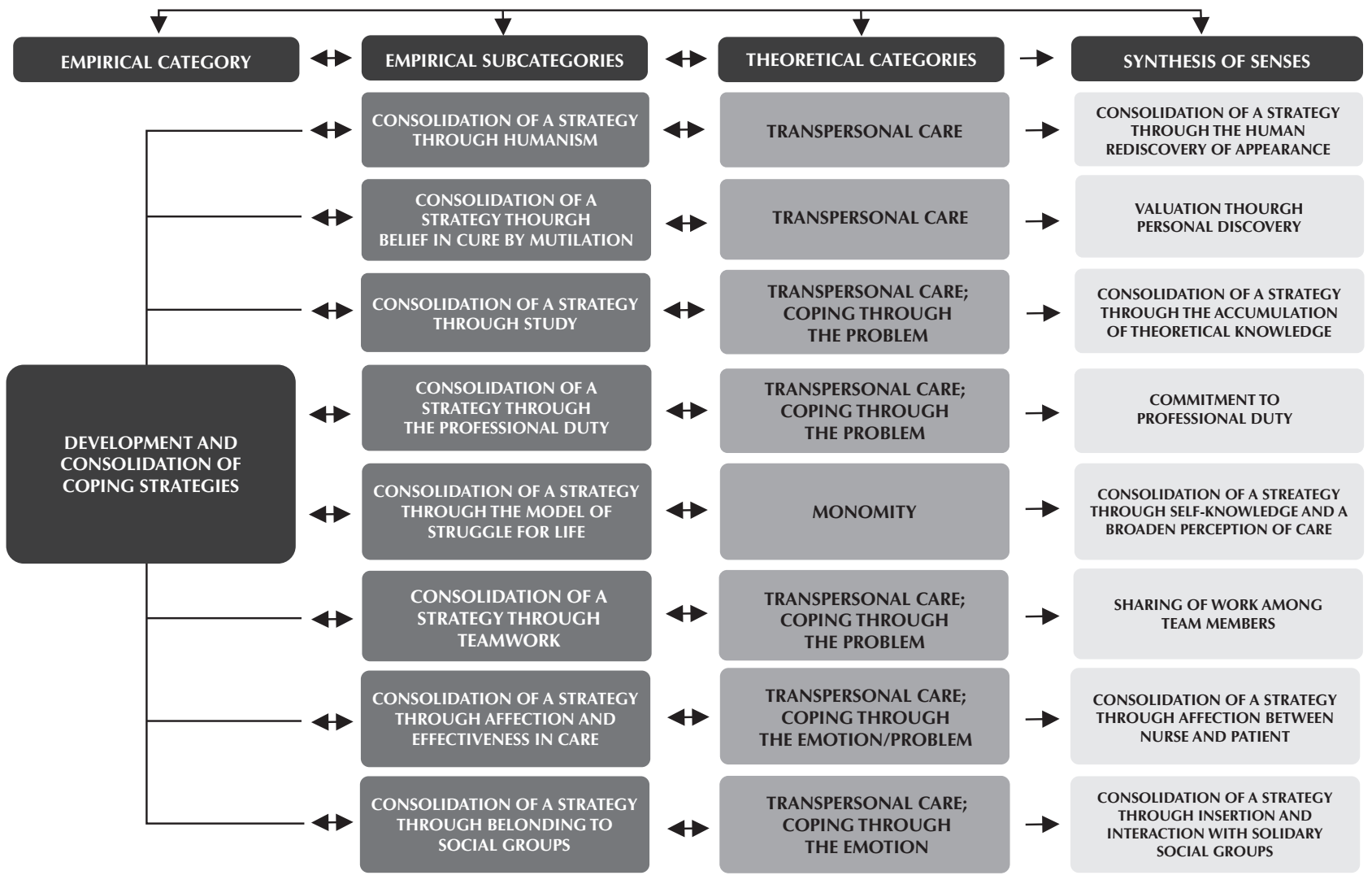

Figure 3 - Scheme of the interpretative analysis process related to the empirical category Development and consolidation of coping strategies. 


\section{DISCUSSION}

Three comprehensive social senses became relevant in the empirical material; each one is connected to one of the categories and their respective subcategories.

\section{THE SENSE OF INITIAL ESTRANGEMENT AND COMPLEXITY} THAT COMPRISE THE CARE TO PATIENT WITH FACIAL IMAGE ALTERATION

In their totality, the speeches comprising the category Initial estrangement of coping point out a sense of estrangement in relation to the consequences of the surgical treatment aggravated by the complexity of the care.

Reactions to mutilation cover the expression of affections and feelings resulting from the early experiences of the care to patients with facial image alteration. The aesthetic characteristics of the patient are detailed: "Head and neck patients are unpleasant to the eyes. There is a distance from the ideal of beauty" (E7). The participants also express the discomfort and fear generated by viewing the image of the patients, exposing the difficulties in the early contacts: "At the time, surgeries presented a high level of mutilation. The reconstructions were terrible. Patients looked like horrible simians. So I was very scared; in fact, on that first day of duty, I talked to the person in charge and said that I would not be able to deal with that" (E1). There is a contradiction evidenced by the senses of rejection and solidarity, simultaneously: "My God, how can a person be in this situation and look well, talking with me? Then I returned stronger to do his dressing" (E6). The reactions to the disfiguration involve the relation with the other, who, even though they might be alike, looks different. Such reactions, if impregnated with social stigma, may awaken a latent prejudice or a projective identification $^{(13)}$ in the occurrence of assimilation of an individual by the other in the process of transference of the person or situation experienced: "The infested wounds caused me rejection. I thought: 'Guys, I think I couldn't go out to the streets in this situation"' (E7).

Unlike rejection, in mutilation there is the identification of a motivating element to overcome and mitigate the initial estrangement: "Of course they [mutilated faces] generated an impact, but it was for my professional development" (E5). It is possible that, even implicitly, the interviewee expressed an emotional intelligence, an ability to control the emotions and motivate themselves ${ }^{(14)}$ when dealing with their own feelings. They were able to adapt them to the experienced situation as they experience them by putting them at the service of professional performance and development in a daily exercise of practical intelligence ${ }^{(15)}$. This is identified as practical emotional intelligence due to its relation between thought and action.

Another way to deal with the initial estrangement is a kind of appeal to the senses of vocation and mission attributed to modern nursing that some nurses seem to internalize as a providential option to overcome emotional obstacles in professional practice when dealing with facial mutilation. Vocation and mission stem from concepts, ideals, and stereotypes historically established that influence the understanding of the meaning of nursing as a health profession. In the construction of this professional model, the legacy of the founder of modern nursing ${ }^{(16)}$ Florence Nightingale is decisive. This is both due to the notion of vocational skills reaffirmed by education and work as enhancements and to the idea of a profession with a missionary nature, namely: I faced the facts smoothly. My reaction was to help the doctor with the dressings. For me it was normal. "I was neither horrified, nor was scared or frightened. I think that from that moment I felt that I had been chosen" (E2).

Reactions to the social context of the patient evidence expressions related to the social stigmatization of patients by their own families. While most reactions focus on facial appearance, some found in the behavior of family members the causative elements of the initial estrangement: "What affected me and made me feel bad was the son complaining that his father smelled bad and that he didn't want to stay with the patient. He wanted him to be hospitalized. He wanted to leave him there and all" (E2). Social stigmatization may be motivated by fear, lack of esteem, disgust, rejection, or prejudice. Having cancer produces physical, emotional, affective, professional, and financial implications for patient and his family, leading to stress, tension, and conflict $^{(17)}$.

Empathy and feminine identity cover a sense of identification of the nurse with the patient, possibly due to their social condition of being a woman. The initial coping does not occur through distancing, fear, or rejection. The care represents an interpersonal meeting with therapeutic and comfort purposes, and is strengthened by welcoming, solidarity, and empathy with the patient ${ }^{(18)}$. The focus is not on the disease, but in the condition of the woman: "There was nothing so shocking like this... Except for putting myself in the place of those women undergoing tracheotomy" (E3).

In reactions to the unknown a hybrid sense of insecurity and mobilization was found. In insecurity, it is necessary to face the uncertainties of the unknown: "I felt helpless, (...) unable, because during my education I had never provided care to a patient that had undergone tracheotomy. I didn't know that type of patient" (E4). In mobilization it is necessary to change the concept of care through practical learning, and such a challenge represents a source of inspiration for professional development: "It was very challenging. I had to face a new view of nursing care, rich in care, very rich, in which I could learn a lot and also offer my best" (E4). Both reactions refer to the idea of a bridge between education and dedication to work as professional improvement. The care practice represents the core of nursing and the tone for transpersonal relations that generates insecurities and mobilizations in the process of knowledge about themselves and others ${ }^{(18)}$.

Mutilation as a cure involves a sense - immersion in common sense - that the surgical removal of the tumor consists of the definitive eradication of the disease, maybe as an attempt to justify the losses and deformations resulting from the surgeries, reinterpreting the condition of the patient in a positive manner ${ }^{(2)}$, as the possibility of cure through surgery is opposed by a probable irreversible 
evolution of the disease: "In surgical cases you have mutilation, but at least that individual was free from cancer" (E7).

\section{THE SENSE OF THRESHOLD BETWEEN THE ESTRANGEMENT AND COPING THAT MAKE UP THE EMERGENCE OF COPING STRATEGIES DURING CARE}

The prevailing sense in the category Emergence of coping strategies evidences the early cognitive and behavioral tests of identification of strategies by nurses when they were inserted in the threshold between the initial estrangement and the coping. It is also possible to interpret the sense of threshold as a borderline between internal/external problematic situations (initial estrangement) and development/ affirmation of the professional identity (coping).

Coping through imagination involves abstraction of the real appearance by the projection of an idealized appearance, indicating a transition between the initial estrangement and the search for a coping strategy conducted by cognitive changes and behavioral efforts intended to manage specific (personal) and/or external (environmental) demands resulting from stressing events ${ }^{(2,8)}$. The identification of the coping strategy is based on emotion (idealized projection, possibly as a defense mechanism): Therefore, as a matter of humanity, I tried to create a perfection mask. Your nose is not there, but it is okay. "(...) Those realities literally became normal. Each day I tried to forget about the face. I had to be used to that. It is my profession" (E1).

Coping through affection translates a sense arising from daily relations between nurses and patients as a triggering element of the identification of the coping strategy that may have a new meaning as a positive interpretation ${ }^{(8)}$, enabling the nurse to aggregate the production of emotions to their occupation ${ }^{(19)}$. Such a process is inherent to the care, particularly in nursing ${ }^{(18)}$, as it implies sensitivity and coparticipation: “(...) patients have brought me so much affection, so much attention, so much emotional dependence, so I became a kind of mother" (E1).

The subcategory coping through altruism points out a sense of balance of the emotions resulting from the initial estrangement, through the initiative to help from the personal dimension, and transcends the professional dimension, focusing on the exclusive benefit of patient care. It implies availability of the I to the Other, creating a possible reception to what the Other offers differently from the $\mathrm{I}^{(20)}$. The condition of the Other impels the I to dedicate attention to him/her. The welcoming by the I is determined by the needs of the Other: "I don't know if I have inside myself a certain strength to deal with that (...). Always trying to mobilize myself internally in the sense of helping the person" (E7).

Coping through the professional duty is the deontological aspect, indicating a moral choice in view of the coping, a conscious decision to do what has to be done, with the professional attributions as triggering factors of the coping strategies. To operate as a driving force, the professional duty requires provision of an environment that offers support, protection and, according to the context, a kind of mental, physical, and spiritual neutralization ${ }^{(18)}$. "My duty as a nurse is to provide care to patients as a whole, from the beginning, without judging and without demonstrating any type of revulsion/horror in relation to their image" (E4).

Coping through separation between professional and personal lives points out a supposed separation between the experiences of the professional practice and the personal daily life requiring a problematization, as there are controversies in relation to the possibility of a total separation between them. The promotion of mutual emotional ignorance between professional and personal experiences is a defensive strategy of sleight ${ }^{(8)}$, avoiding reflection on the actual consequences of such separation. In general, there is a harmful superposition of the professional life over the personal life by means of an increasing negligence of this in favor of that ${ }^{(21)}$. In both experiences (professional and personal) the absence of praxis is envisioned, that is, the non-thinking about the doing, establishing an experiencing that is not reflected in the recent experience as "The experiencing differs from the experience because it consists in the elaboration of the individual about everything they experience"(22). The interviewee does not seem to immerse herself into the most severe meanings of her experience, which may represent a way to mitigate the adverse feelings of a stressing condition: "I live there, to that moment of care. When I leave that moment I disconnect myself. It is as if that was unreal and I was looking to experience other things. I avoid thinking too much" (E5).

In coping through study there is the investment in the accumulation of knowledge as a triggering factor of a possible coping strategy. Attempt to change the reality that causes estrangement occurs through the acquisition of information and knowledge that would enable the appropriate coping with adverse situations of the labor practice. This would characterize a problem-based strategy ${ }^{(2,8)}$, if considered the intention of the nurse to intervene on the source of tension: "I researched articles. I start to read because in the articles (...) some articles state that the family is the second patient of the nurse" (E8).

Coping through teamwork also refers to a problembased strategy ${ }^{(2,8)}$, with a sense of belief in teamwork as a facilitator of the emergence of coping strategies. The team, understood as a technical body but also as a social group, works as a promoter of the emergence of strategies, consisting in support for the professional work and a source of resolution of problems: "I really like my work team. (...) It is a group that you know you can count on. (...) You know that, in the next duty, they will be together with you, and this is very nice" (E6).

In coping through self-esteem there is the own well-being as a condition to provide care to the other. Providing care to the other requires proving care to oneself as a strategy of coping through the conscious cultivation of self-esteem. Providing care to oneself implies self-care with one of the techniques of the self, which enables the individual to intervene on the part of himself/herself with view to a state of satisfaction ${ }^{(23)}$. Its application is not restricted to nursing ${ }^{(24)}$. It is extended to other professionals, although nurses have a more intense experience in relation to the suffering of others, leading to the lack of a healthy relationship with 
themselves: "I do yoga and Pilates. Yoga to control and stabilize body and mind. And this is very nice" (E6). Another possible reflection refers to questioning whether the selfcare, besides being a necessary condition, is also a sufficient condition, as self-care may not ensure a level of satisfaction that is able to mobilize for the care to others, especially if, to be complete, the state of one's own well-being implies the well-being state of the other, which is not always achieved.

Coping through religiosity considers faith as a confessional feeling, institutionalized or not, that reduces discomfort and tension and propitiates the search for coping strategies. It presupposes a superior being or power to the human condition ${ }^{(25)}$ that works as a promoter of coping through the possibility of overcoming the distress that is inherent to the care: "In religion I seek the strength I need to perform my duty. I am a Spiritualist; my mother is a Spiritualist"(E8). Sometimes religiosity is expressed as part of a doctrine, a system that mediates the relation between the human and the sacred, giving a sense to life and guiding the doing, enabling nurses to transcend estrangement in the presence of the patient. It has an intrinsic function when it integrates the life of the individual, characterizing it as genuinely religious, or extrinsic when it meets the needs of self-protection and safety ${ }^{(25)}$. In addition to the idea of doctrine, the religiosity is expressed through the notion of spirituality that, in relation with the transcendent, unravels the production of a human energy ${ }^{(18,25-26)}$ that is potentially transformative of emotions, attitudes, and behaviors: "Oh, my religion helps a lot. I am a non-practicing Catholic. I have faith in God. I often talk with God. Sometimes I ask Him to rescue me, because sometimes we do not feel well but we have to do our job" (E5). In both of these speeches it is possible to infer that religion represents a source of comfort, favoring the appearance of coping strategies through emotion and through the defensive attitude of an abstraction of reality.

\section{THE SENSE OF IMAGE-LIKENESS AS RE(COGNITION) OF THE INDIVIDUAL WITH FACIAL IMAGE ALTERATION IN THE DEVELOPMENT AND CONSOLIDATION OF THE COPING STRATEGIES DURING CARE}

The major sense present in the category Development and consolidation of coping strategies is that providing care to patients with facial image alteration requires an authentic relationship of mutuality based on the three principles: helpconfidence-empathy. Its contradictions, as well as the vulnerable condition of the patient, also integrate the idiosyncrasies of the human condition. Nurses find and understand themselves as finite beings who are, however, full of infinite possibilities. They recognize that the other, although aesthetically different, exists in their image and likeness, being a co-producer of a care that goes beyond the deontology and technique inherent to the doing in nursing.

Consolidation of strategy through humanism evokes the rediscovery and reaffirmation of the human. After the initial reactions of both nurses and patients there is the occurrence of the phenomenon of transpersonal care ${ }^{(18)}$ through a maturation of human relations: "Over time, less and less I saw the mutilations; and I increasingly saw that being behind that, depending on me, needing me to stimulate them"(E1).

In consolidation through belief in cure by mutilation the conformation of the coping strategy transcends the initial rejection, idealization, and projective identification. It culminates in the recognition of the human dimension that sublimates the vulnerable condition of the patient as it occurs through the rediscovery of the individual patient as greater than the disease and its consequences. Again, subject to the criticism of the idea of cure through mutilation, transpersonal care $^{(18)}$ eventually consists in a distinct way from the aforementioned: "In the beginning it was a little difficult to keep that mask of 'Oh, it is okay,' but then (...) that became usual to me. I got used to them, and I learned with them that it was not really important how they were; the important thing was that they were free from cancer. Their mutilation was much better than the tumor that they had before that" (E1).

Consolidation of strategy through study indicates the appropriation of knowledge as a way to justify the coping. It is related to the consolidation anchored in the technique in relation to the procedures of application and the interpersonal skill during the care, translating into a coping through the problem ${ }^{(2,8)}$. This study as a strategy underlies the ambition of the greater domain of care-related problems. Although focused on the problem, the main focus of the strategy consists in ensuring a better care to the human individual: "That is the reason I am studying. I am doing my master's degree in order to specialize and be able to provide a better care. This is it. It is the strength of will that they have to live. That's all" (E1).

Consolidation of strategy through the professional duty evidences a deontological sense of professional commitment, referring to a moral precept of the Nursing Professionals Ethics Code ${ }^{(27)}$, in which humanism substantiates professional duty and works as a consolidator of the coping strategy: "As a professional, I think that at this moment I am helping them to establish themselves as persons in the face of life. They are strong, undergoing an experience, but they are here and may count on my help at any moment" (E2).

Consolidation of strategy through the model of struggle for life indicates the desire of the patient to live as the triggering factor of a process of self-knowledge in the nurse that, under a broader perception of care permeated by the dualism between vulnerability and bravery, qualifies the patient as a fearless individual that follows their way: "I think that in the face of so many things in life, these people, even suffering, they want to live. So, I think they are heroes" (E4). The journey of the hero as a monomyth ${ }^{(28)}$ consists of three sections (starting, initiation, and return) built from various stages involving trials and putting the individual on the threshold between life and death, thus requiring from them an exceptional determination. If the hero is the one that suffers a rite of transformation ${ }^{(28)}$ it is possible to infer that the hero is also the one who inspires the transformation rite of the other, as the monomyth of the patient inspires the nurse in the consolidation of the coping strategy.

Consolidation of strategy through teamwork points out the shared coping, which as a collective construct 
combines social and emotional aspects and favors the care process: "We sit and talk, and share the problems" (E3) or "Everything you do is a process that has to have the group" (E8). It characterizes coping through the problem ${ }^{(2,8)}$ as the requirement of the social support of the pairs work, because coping during the care demands an environment of support, protection or mental, physical, and spiritual neutralizations ${ }^{(18)}$. Sharing is not restricted to the division of tasks; it also involves the search for solutions to collective and individual difficulties.

Consolidation of strategy through affection and effectiveness of care emphasizes a sense of mutuality resulting from the cooperative relation between patient and nurse, resulting in positive impacts to the physical state of the patient as a result obtained through the care practiced by both. The consolidation of the strategy occurs through the circular movement of mutual affective and effective care, suggesting a transpersonal care $^{(18)}$ of coping through emotion ${ }^{(2,8)}$ based on a relationship of help and confidence between nurse and patient. It marks the care process as a precious experience of authentic, ethical, and intentional care: "We always learn from patients. Once a patient helped me.I was facing a personal problem. He prayed for me. And came to know if I was feeling better. And this helped me wonderfully. This makes me a happy person, because I work in a place that I like and I have a return both from patients and the wounds that are healed"(E2).

In consolidation of strategy through belonging to social groups the attribution of senses is focused on the idea of insertion into and interaction in solidarity social groups. Apparently the consolidation of the coping strategy is expressed through the search for solidarity as a formal or informal social support that may be characterized as coping through emotion ${ }^{(2,8)}$. This occurs in two distinct senses: as a transpersonal care ${ }^{(18)}$ practiced in social groups acting as a support to the nursing care practice, and as a defensive behavior marked by a certain level of distance. In the latter, attempts to regulate the emotional impact of the coping of the individual with the difficult and stressing realities become diffuse between religion, family, and friends: "It was in fact my religion, my friends, my family, daily events. So, for myself, I was looking for something, too" (E5).

\section{CONCLUSION}

The report of the professional life history of nurses in the care of patients with facial image alteration enabled a better approximation of the processes of identification, development, and consolidation of the coping strategies and their respective reinterpretations. For most nurses the initial estrangement in dealing with these particular patients was permeated by both technical-scientific and emotional difficulties. Despite the difficult beginning, however, their professional histories were marked by discoveries and rediscoveries of themselves and others, developing them both as human beings and as professionals. The consolidation of coping strategies enabled the evolution of an initial situation of estrangement to a situation of satisfaction and consolidated care.

In addition to the technical and emotional aspects, nurses exercised their ability to overcome by means of one of the more valued attributes in nursing: recognition of the human condition marked by the fortuity of life in an awareness of the singularity that makes up each individual. The conscious search for solutions to the daily practice problems in the care favors decision-making and the effective and appropriate adjustment processes. Considering the complexity of the care within the area of oncology, the identification and understanding of coping strategies may be useful to the curricular planning in the training of future nurses, thus contributing to a better qualification of the nursing care. The training of these nurses must be able to bridge the existing gap in the preparation of this professional to deal with the typical adversity inherent to oncologic nursing.

A possible goal would consist in reducing the time between the initial estrangement - marked by the difficulty of absorption - and the consolidation of coping strategies. This would facilitate the coexistence with the adverse and stressing situations and enable future nurses to alter or mitigate the cognitive and emotional challenges resulting from them. From a perspective of future developments from this research, more in-depth studies in the fields of Pedagogy and Psychology may contribute to the consolidation of an appropriate professional profile to meet the specificities of the nursing care to patients with head and neck neoplasms.

\section{RESUMO}

Objetivo: Compreender e descrever a experiência de desenvolvimento de estratégias de enfrentamento durante a vida profissional de enfermeiras no cuidado aos pacientes com imagem facial alterada. Método: Pesquisa qualitativa descritiva, com referencial hermenêuticodialético, realizada na Seção de Cabeça e Pescoço de um hospital de referência do Rio de Janeiro, com participação de oito enfermeiras e dados produzidos por meio de entrevista semiestruturada entre junho e agosto de 2013. Resultados: Emergiram três amplos sentidos: estranhamento e complexidade iniciais, que constituem o cuidado ao paciente com imagem facial alterada; limiar entre estranhamento e enfrentamento, correspondendo à emersão das estratégias de enfrentamento durante o cuidado; e imagem-semelhança como (re) conhecimento da pessoa com imagem facial alterada no desenvolvimento e na consolidação das estratégias de enfrentamento durante o cuidado. Conclusão: Entre outras contribuições, a identificação e a compreensão das estratégias de enfretamento podem contribuir para melhor qualificar a formação e a assistência de enfermagem.

\section{DESCRITORES}

Neoplasias de Cabeça e Pescoço; Adaptação Psicológica; Enfermagem Oncológica; Pesquisa Qualitativa.

\section{RESUMEN}

Objetivo: Comprender y describir la experiencia de desarrollo de estrategias de enfrentamiento durante la vida profesional de enfermeras en el cuidado a los pacientes con imagen facial alterada. Método: Investigación cualitativa descriptiva, con referencial hermenéutico-dialéctico, llevada a cabo en la Sección de Cabeza y Cuello de un hospital de referencia de Río de Janeiro, con la 
participación de ocho enfermeras y datos producidos mediante entrevista semiestructurada entre junio y agosto de 2013. Resultados: Emergieron tres amplios sentidos: extrañamiento y complejidad iniciales, que constituyen el cuidado al paciente con imagen facial alterada; umbral entre extrañamiento y enfrentamiento, correspondiendo a la emersión de las estrategias de enfrentamiento durante el cuidado; e imagen-semejanza como (re)conocimiento de la persona con imagen facial alterada en el desarrollo y la consolidación de las estrategias de enfrentamiento durante el cuidado. Conclusión: Entre otros aportes, la identificación y la comprensión de las estrategias de enfrentamiento pueden contribuir para mejor cualificar la formación y la asistencia de enfermería.

\section{DESCRIPTORES}

Neoplasias de Cabeza y Cuello; Adaptación Psicológica; Enfermería Oncológica; Investigación Cualitativa.

\section{REFERENCES}

1. Brasil. Ministério da Saúde; Instituto Nacional de Câncer José Alencar Gomes da Silva. Estimativa 2014: incidência de câncer no Brasil [Internet]. Rio de Janeiro: INCA; 2014 [citado 2014 fev. 11]. Disponível em: http://www.inca.gov.br/estimativa/2014/estimativa-24012014.pd

2. Gomes SFS, Santos MMCCS, Carolino ETMA. Psycho-social risks at work: stress and coping strategies in oncology nurses. Rev Latino Am Enfermagem. 2013;21(6):1282-9.

3. Grazziano ES, Bianchi ERF. Impacto do stress ocupacional e burnout para enfermeiros. Enferm Glob [Internet]. 2010 [citado 2015 set. 28];(18). Disponible en: http://revistas.um.es/eglobal/article/viewFile/93801/90461

4. Edmonds C, Lockwood GM, Bezjak A, Nyhof-Young J. Alleviating emotional exhaustion in oncology nurses: an evaluation of Wellspring's "Care for the Professional Caregiver Program". J Cancer Educ. 2012;27(1):27-36.

5. Lazzarin M, Biondi A, Di Mauro S. Moral distress in nurses in oncology and haematology units. Nurs Ethics. 2012;19(2):183-95.

6. Mark G, Smith AP. Occupational stress, job characteristics, coping, and the mental health of nurses. Br J Health Psychol. 2012;17(3):505-21.

7. Maron M, Koslowsky M. Relationships between changes in role stressors and intention to quit among novice nurses. Eur J Bus Soc Sci. $2013 ; 2(1): 1-14$.

8. Moskowitz JT, Shmueli-Blumberg D, Acre M, Folkman S. Positive affect in the midst of distress: implications for role functioning. J Community Appl Soc Psychol. 2012;22(6):502-18.

9. Dal Pai D, Lautert L. Estratégias de enfrentamento do adoecimento: um estudo sobre o trabalho da enfermagem. Acta Paul Enferm. 2009;22(1):60-5

10. Araújo JL, Paz EPA, Moreira TMM. Hermeneutics and health: reflections on the thinking of Hans-Georg Gadamer. Rev Esc Enferm USP [Internet]. 2012 [cited 2015 Sep 28];46(1):194-201. Available from: http://www.scielo.br/pdf/reeusp/v46n1/en_v46n1a27.pdf

11. Minayo MCS. Análise qualitativa: teoria, passos e fidedignidade. Ciênc Saúde Coletiva. 2012;17(3):621-6.

12. Gubrium JF, Holstein JA, editors. Handbook of interview research: context and methodology. Thousand Oaks: Sage; 2001.

13. Laplanche J, Pontalis JB. Vocabulário de psicanálise. $4^{a}$ ed. São Paulo: Martins Fontes; 2001.

14. Goleman D. Inteligência emocional. 10ª ed. Lisboa: Temas e Debates; 2001.

15. Dejours $C$, Abdoucheli E, Jayet C. Psicodinâmica do trabalho: contribuições da escola Dejouriana à análise da relação prazer, sofrimento e trabalho. São Paulo: Atlas; 1994.

16. Lee G, Clark AM, Thompson DR. Florence Nightingale: never more relevant than today. J Adv Nurs. 2013;69(2):245-6.

17. Glajchen M. Physical well-being of oncology caregivers: an important quality-of-life domain. Semin Oncol Nurs. 2012;28(4):226-35.

18. Watson J. Human caring science: a theory of nursing. Ontario: Jones \& Bartlett; 2012.

19. Aldridge, M. Unlimited liability? Emotional labour in nursing and social work. J Adv Nurs. 1994;20(4):722-8.

20. Lévinas E. Totalidade e infinito. Lisboa: Edições 70; 1980.

21. Elias MA, Navarro VL. A relação entre o trabalho, a saúde e as condições de vida: negatividade e positividade no trabalho das profissionais de enfermagem de um hospital escola. Rev Latino Am Enfermagem. 2006;14(4):517-25.

22. Minayo MCL. Los conceptos estructurantes de la investigación cualitativa. Salud Colectiva. 2010;6(3):251-61.

23. Foucault M. Historia de la sexualidad 3: la inquietude de sí. $2^{\text {a }}$ ed. Buenos Aires: Siglo Veintiuno; 2010.

24. Silva IJ, Oliveira MFV, Silva SED, Polaro SHI, Radünz V, Santo EKA, et al. Care, self-care and caring for yourself: a paradigmatic understanding thought for nursing care. Rev Esc Enferm USP. 2009;43(3):690-5.

25. Ekedahl MA, Wengström Y. Caritas, spirituality and religiosity in nurses coping. Eur J Cancer Care. 2010;19(4):530-720.

26. Ramezani M, Ahmadi F, Mohammadi E, Kazemnejad A. Spiritual care in nursing: a concept analysis. Int Nurs Rev. 2014;61(2):211-9.

27. Conselho Federal de Enfermagem. Resolução n. 441, de 23 de maio de 2013. Dispõe sobre participação do enfermeiro na supervisão de atividades prática e estágio supervisionado de estudantes dos diferentes níveis da formação profissional de enfermeiro [Internet]. Brasília: COFEn; 2013 [citado 2015 set. 28]. Disponível em: http://novo.portalcofen.gov.br/resolucao-cofen-no-4412013_19664.html

28. Campbell J. O herói de mil faces. São Paulo: Cultix; 1997. 